\title{
Initiating a New Research Phase in the Field of International Entrepreneurship: An Interview with Professor Nicole Coviello
}

\author{
Nicole Coviello and Stoyan Tanev
}

\author{
(' International entrepreneurship research seems to be") \\ at the cusp of moving from... a 'poorly understood \\ emergence phase' of identity development to one \\ that is better understood.
}

Nicole Coviello (2015)

Professor of Marketing, International Business, and Entrepreneurship

\section{Introduction by Stoyan Tanev}

The internationalization of businesses has become a pervasive phenomenon worldwide. In the international business literature, firms that internationalize early in their life cycle are referred to as "born globals" (Rennie, 1993), "international new ventures" (Oviatt \& McDougall, 1994), "global startups" (Oviatt \& McDougall, 1995), or "instant internationals" (Fillis, 2001). The term born global, however, has acquired a dominant position despite being defined in different ways by different scholars. Although many firms target global niches and develop a global presence from or within one or two years of their founding, they may not fit any of the existing definitions of "born global". One of the reasons for the variety of perspectives could be that research on born-global firms and international new ventures has necessarily brought together two different research domains - international business and entrepreneurship and, accordingly, there has been the quick emergence of the international entrepreneurship research field.

In addition, research on born-global firms and international new ventures has become highly relevant in the context of technology entrepreneurship and has attracted the attention of scholars and practitioners in this area. Today, many new technology firms are in a better position to target competitive positions in international markets by working with global partners to innovate and pilot new disruptive technologies. The latest research suggests that the information age has enabled the adoption of a new techno-economic vision for the emerging structures and processes in international business in general. The reality of the newly emerging paradigm includes the changing nature of the competit- ive advantages of places, the competitive advantages and strategies of firms, and the governance structure of international business networks (Alcácer et al., 2016). Unfortunately, the terminological inconsistency in international business and international entrepreneurship research does not help practitioners to develop design principles for the creation and launching of new, globally competitive high-tech startups.

In a recent publication, Nicole Coviello (2015) emphasized the need to re-think existing research on international entrepreneurship and, more specifically, research on born-global firms. She pointed out that the main value of a critical review lies in initiating a new research phase focusing on the development of a more consistent collective research identity for international entrepreneurship through an ongoing process of terminological refinement and clarification. Here, I present my recent interview with Nicole Coviello, which was inspired by her recent publication. It focuses on issues that could be of relevance for new technology firms aiming at an international or global engagement from their very inception.

\section{Interview with Nicole Coviello}

Tanev: Prof. Coviello, your call for a terminological refinement suggests our first question: What is your definition of a born-global firm? How does it compare to other such definitions and what is the key difference that you would like to emphasize?

Coviello: I think the point might be more about clarification than refinement. I have long resisted using the term "born global" for two reasons. First, it was pre- 


\section{Initiating a New Research Phase in the Field of International Entrepreneurship}

An Interview with Professor Nicole Coviello

ceded in academic literature by the "international new venture typology from Tricia McDougall and Ben Oviatt: a typology that identified four different forms of international new venture. To me, that typology was a clear signal that multiple organizational forms are relevant in international research and labelling all international new ventures as "born globals" misses that point. Second, the term "born global" presumes the firm is founded on the global stage. However, although research has been talking about born globals since 1996, I believe it is only now that digital technology truly facilitates "born global-ness". I'd argue that most of our past research in international entrepreneurship has not been about born globals but rather, born internationals or born regionals (and even those labels imply the firms were founded with the intent to pursue international or regional expansion). The term "born global" has been over-used and mis-used because it's a catchy phrase.

My opinion (and practice) is that if one wants to study a born-global firm, then that firm should have been founded with the intent to serve global markets and then done so. Of note - this means being able to understand intent at founding: was globalization part of the founding intent or did the firm just happen to get pulled into international markets? The distinction is important because the behaviours of a proactive versus reactive firm are quite different. Furthermore, I believe it's important to clarify where the firm is relative to founding. For example, data collected on a 2-3 year-old firm is very different from that collected from a 10 year-old firm, even if you make the argument they are both "born global". The latter have survived early internationalization (that may or may not have been rapid). The former may still be in the process of internationalizing. They are not equivalent.

In a nutshell, the label "born global" was a lot more brandable than "international new venture". There are other differences too but, if I could, I would wave a magic wand so that every study in international entrepreneurship clearly described their firms and founding intent without using the born-global label.

Tanev: My interest in the field of international entrepreneurship turns around new technology-based firms that engaged into a global path from their very inception. The logic behind this interest is the following: If technology firms that are born global are more successful than firms that are not born global, we should focus on defining and implementing design principles that incorporate key attributes of born-global firms and use these principles to launch and grow new companies. Our logic is based on the assumption that born-global technology startups are expected to be more successful than technology firms that did not engage into a global path from the very beginning. What does international entrepreneurship research say about that - how solid is the empirical evidence suggesting a basis for such assumption?

Coviello: Before I answer your question, I want to make a few clarifying points. First, until recently, very few firms truly had the possibility of engaging on a global path. Global means global. International is not quite as broad in scope. Regional is closer to home. Only now, with the emergence of what I call finger-push firms, do we have a wide range of companies with the potential to serve global markets. That's because their offer is fully digitized, and all that is required for them to reach/communicate with/serve markets around the global is the push of a button on a computer. With 3D printing, even the sourcing of product becomes obsolete. Second, another point to keep in mind when conceptually discussing a born-global firm pertains to international expansion speed. Speed is another term that has been used too casually. Most speed research isn't about speed at all but rather it is about timing. My opinion is that, to study speed, you need to consider whether you are interested in: i) timing (e.g., time to first foreign market entry); ii) pace of ongoing internationalization, or iii) the rhythm of internationalization over time. Those are three very different concepts.

So where does success come in? I have two thoughts. First, no, I don't think that we have sufficient evidence in international entrepreneurship research to suggest that born globals are more successful. We assume they are. We also assume that internationalization speed is beneficial. But true born globals and speed need more attention in research. Second, we are only now able to compare born globals and non-born-globals because we can compare, for example, software-as-a-service (SaaS) firms with software developers. Both fall into the "software" sector but only one (SaaS) has the potential to be born global; the other is much more likely to be born regional or born international. Again, we don't yet have sufficient empirical evidence on firms that are truly born global versus masquerading as such (because of how authors have labelled the firms they study).

Tanev: If you were to distill the practical implications of a decade's work on born globals and your re-thinking of the concept, what are the key points the individual entrepreneur should take away and apply in starting a new global business today? 


\section{Initiating a New Research Phase in the Field of International Entrepreneurship}

An Interview with Professor Nicole Coviello

Coviello: Get into SaaS if you want to be "global". If you are in technology manufacturing, exploring the Internet of Things or artificial intelligence, or developing software, know there is a global market but your business is likely to be strongest by serving select markets and customers carefully and well. You don't need to be global to be successful.

Tanev: Recently, you have also pointed out that, for scholars working at the interface of international business and entrepreneurship, an understanding of entrepreneurial business models is essential (Coviello, 2016). Where do you see the potential and challenges of integrating research into business models, born globals, and international new ventures?

Coviello: It's important to remember that international entrepreneurship research and practice sit at the intersection of international business and entrepreneurship. The relevance of the business model literature comes from entrepreneurship and while we have happily adopted concepts like entrepreneurial orientation into the international entrepreneurship literature, we've been slow to recognize how international entrepreneurship parallels entrepreneurship arguments regarding business models. Your work is one of the very few exceptions (Rasmussen \& Tanev, 2015).

Tanev: In your discussion of the global entrepreneurial potential of business model research, you have also referred to the growing interest in the lean startup entrepreneurial approach and the possibility of considering lean global startups as a new type of organization/firm (Rasmussen \& Tanev, 2015). By "lean startup approach", we mean the specific hypothesis-driven entrepreneurial approach that "favors experimentation over elaborate planning, customer feedback over intuition, and iterative design over traditional 'big design up front' development" (Blank, 2013), which is based on several concepts such as minimum viable product and pivoting. Do you personally see a reason for the adoption of the lean startup approach within the context of born-global firms? Does integrating lean startup and born global research allow for the identification of a new type of firm, or at least a unique growth mode, that deserves to be considered separately from others?

Coviello: From a practical perspective, it is good news that the lean startup approach has been widely popularized. Practitioners like it and lean captures all the advantages of being nimble and with little to unlearn. Steve Blank has done a great job of popularizing concepts that have been core to entrepreneurship theory for some time (e.g., arguments from Howard Stevenson or Saras Sarasvathy). That is, "lean” isn't really new it's just that Blank makes the ideas digestible and, I think, more tangible for practitioners. It does, however, set the stage well for internationalization. At any rate, I don't consider a lean global startup to be a new form of organization or growth mode. Lean is a way of operating. In the same way that we study organization structure, orientation, etc., we should study the influence of lean (or effectual logic) as young firms internationalize.

Tanev: There seems to be an ongoing tendency to consider the field of innovation management in the broader context of business model innovation. We believe that there is a point in such claim, given that an innovation usually affects all the components of a business model. Your call for integrating international entrepreneurship and business model research should therefore inspire more research focusing on innovation management in a global entrepreneurial context. But why is there so little international entrepreneurship research focusing on innovation management? The few articles in this area do not seem to have a major impact. What are the challenges, theoretical or conceptual, the addressing of which would help in integrating early internationalization and innovation research with a focus on new entrepreneurial firms?

Coviello: I think one of the challenges comes from the heritage of international entrepreneurship. Most researchers have come from an international-business-related area or from entrepreneurship whereas innovation is a distinct third discipline. Marian Jones and I tried to bring innovation into the international entrepreneurship discussion with our paper in the Journal of International Business Studies (Jones \& Coviello, 2005), but you are right, there is more to be done.

Tanev: Please tell us more about your understanding of the priorities of the new international entrepreneurship research phase you are calling for. In your recent paper, you refer to the need for more international entrepreneurship and international business research at the level of the individual entrepreneur and especially in the context of the next generation of young founders emerging from our entrepreneurship programs. But where do you see other similar needs, what type of future research is needed, and are there other research themes that have become urgent and need to be addressed?

Coviello: My interest in the "people of international entrepreneurship" comes from arguments that any decision or action at the firm level stems from an 


\section{Initiating a New Research Phase in the Field of International Entrepreneurship}

An Interview with Professor Nicole Coviello

individual or team. As a result, I encourage multi-level research and attention to decision makers in the firm. In terms of young founders, I think they are different in terms of how they relate to technology and the world; these differences need to be understood. They don't see the technological, cultural, or national barriers that previous generations did, and I suspect this will influence how they lead their firms. Returning to the concept of a true born global (i.e., a finger-push firm that can instantly set up a global operation), they might turn all our traditionally accepted wisdom on its head. We need to study these firms.

Tanev: Finally, do you see any undergoing changes in the global business environment? What changes or trends in the business environment may need to be addressed in our future research? Where do you think international entrepreneurship research will be 10 years from now?

Coviello: I think my previous answer leads into this one. Understanding, for example, ownership, location$\mathrm{al}$, or internalization advantage was essential when firms expanded by geographic footprint. Things change when expansion is by "finger-push". Our new research needs to recognize that major global players are likely to be located in one region (e.g., main technology centres) and serve the world from either that location or perhaps with small groups of employees working remotely. I hope that 10 years from now, international entrepreneurship research will be a richer blend of international business, entrepreneurship, plus innovation and technology management research.

Tanev: Thank you very much, Prof. Coviello. We greatly appreciate your time and insights for TIM Review readers worldwide.

\section{Summary by Stoyan Tanev}

There are several points in the above interview to be highlighted in the context of the present special issue:

1. Using the term "born global" is not recommended because of the improper semantic implications generated by the term "born." Very few firms were really "born" on a global scene and, as a result, most of international entrepreneurship research so far has not been really studying born globals but rather, born internationals or born regionals. In this sense, the global startup terminology is more appropriate.
2. According to Coviello, it is only now that digital technology truly facilitates "born global-ness". An example of true born global is a finger-push firm that can instantly set up a global operation. Such firms might disrupt our traditionally accepted wisdom. International entrepreneurship research needs to focus on studying these firms.

3. If you want to be "global", get into SaaS. If you are in technology manufacturing, exploring the Internet of Things or artificial intelligence, or developing software, know there is a global market but remember that you do not need to be global in order to be successful.

4. International entrepreneurship research needs to embrace business model frameworks that could enhance the conceptualization of all business aspects in an international/global context.

5. The lean startup approach is not really new but it made entrepreneurial ideas more digestible, more tangible, and more actionable for practitioners, setting the stage well for early internationalization. In this sense, a lean global startup does not seem to be a new form of organization or special type of growth mode: it is more like a specific way of operating. For a more detailed discussion of this point, please see my article in this special issue: "Is there a Lean $\mathrm{Fu}$ ture for Global Startups?” (Tanev, 2017).

6. The challenges of managing innovation in a global context come from the fact that most international entrepreneurship researchers have come from an international business related area or from entrepreneurship whereas innovation is a distinct third discipline. The international entrepreneurship research community has to work on further integrating innovation management scholarship in parallel to business model design and innovation frameworks and theories.

7. Multi-level research and attention to the actual decision makers of global startups should be strongly encouraged. Young founders are different in terms of how they relate to technology and the world. They deserve a special attention and need to be further studied.

8. In the near future, international entrepreneurship research will be a richer blend of international business, entrepreneurship, innovation, and technology management research. 


\section{Initiating a New Research Phase in the Field of International Entrepreneurship}

An Interview with Professor Nicole Coviello

Nicole Coviello is the Lazaridis Research Professor and Professor of Marketing at Wilfrid Laurier University in Waterloo, Canada. She received her $\mathrm{PhD}$ in Marketing and International Business from the University of Auckland, New Zealand, in 1994. She also holds an MSc (Technology Management) and BComm Hons (Marketing) from the University of Saskatchewan in Saskatoon, Canada. Dr. Coviello began her career at the University of Waikato, New Zealand, and has since held positions at the University of Calgary, Canada, and the University of Auckland. In 2010, she received an Honorary Doctorate from the Turku School of Economics in Finland. Dr. Coviello has published in the top journals across three disciplines - marketing, international business, and entrepreneurship. In 2014, she was ranked as one of the top scholars in International Marketing and among the top 20 International Business scholars. She is Field Editor for both marketing and international entrepreneurship at the Journal of Business Venturing.

Stoyan Tanev is an Associate Professor in the Department of Technology and Innovation, Faculty of Engineering, Southern Denmark University (SDU) in Odense. Dr. Tanev is leading the Technology Entrepreneurship stream of the Master Program of Product Development and Innovation at SDU. He is also an Adjunct Research Professor in the Sprott School of Business at Carleton University in Ottawa, Canada, where he is associated with the Technology Innovation Management Program. He has a MSc and a PhD in Physics jointly from the University Pierre and Marie Curie, Paris, France, and the University of Sofia, Bulgaria, a PhD in Theology from the University of Sofia, Bulgaria, an MEng in Technology Innovation Management from Carleton University, Canada, and an MA from the University of Sherbrooke, Canada. He has multidisciplinary research interests with a focus on the fields of global technology entrepreneurship, technology innovation management, business model design, and value co-creation. Dr. Tanev is Senior IEEE member, as well as member of the editorial boards of the Technology Innovation Management Review, the International Journal of Actor-Network Theory, and Technological Innovation.

\section{References}

Alcácer, J., Cantwell, J., \& Piscitello, L. 2016. Internationalization in the Information Age: A New Era for Places, Firms, and International Business Networks? Journal of International Business Studies, 47(5): 499-512.

http://dx.doi.org/10.1057/jibs.2016.22

Bailetti, T. 2012. What Technology Startups Must Get Right to Globalize Early and Rapidly. Technology Innovation Management Review, 2(10): 5-16.

http://timreview.ca/article/614

Blank, S. 2013. Why the Lean Start-Up Changes Everything. Harvard Business Review, 91(5): 63-72.

Coviello, N. E. 2015. Re-Thinking Research on Born Globals. Journal of International Business Studies, 46(1): 17-26. http://dx.doi.org/10.1057/jibs.2014.59

Coviello, N. E. 2016. Implications of Business Models for IE Research. ie-scholars.net. Accessed May 1, 2017: http://ie-scholars.net/blog/2692

Fillis, I. 2001. Small Firm Internationalisation: An Investigative Survey and Future Research Directions. Management Decision, 39(9): 767-783. http://dx.doi.org/10.1108/00251740110408683

Jones, M. V., \& Coviello, N. E. 2005. Internationalisation: Conceptualising an Entrepreneurial Process of Behaviour in Time. Journal of International Business Studies, 36(3): 284-303. http://dx.doi.org/10.1057/palgrave.jibs.8400138

Oviatt, B. M., \& McDougall, P. P. 1994. Toward a Theory of International New Ventures. Journal of International Business Studies, 25(1): 45-64. http://dx.doi.org/10.1057/palgrave.jibs.8490193

Oviatt, B. M., McDougall, P. P., \& Loper, M. 1995. Global Start-Ups: Entrepreneurs on a Worldwide Stage. The Academy of Management Executive, 9(2): 30-44. http://www.jstor.org/stable/4165256

Rasmussen, E. S., \& Tanev, S. 2015. The Emergence of the Lean Global Startup as a New Type of Firm. Technology Innovation Management Review, 5(11): 12-19. http://timreview.ca/article/941

Rennie, M. W. 1993. Global Competitiveness: Born Global. McKinsey Quarterly, 4: 45-52.

Tanev, S. 2017. Is There a Lean Future for Global Startups? Technology Innovation Management Review, 7(5): 6-15. http://timreview.ca/article/1072

Citation: Coviello, N., \& Tanev, S. 2017. Initiating a New Research Phase in the Field of International (cc) BY Entrepreneurship: An Interview with Professor Nicole Coviello. Technology Innovation Management Review, 7(5): 52-56. http://timreview.ca/article/1077

Keywords: international entrepreneurship, international business, born global, international new ventures, lean and global startups, internationalization, definitions 